Abstracta Iranica Abstracta Iranica

Revue bibliographique pour le domaine irano-aryen

Volume 42-43 | 2021

Comptes rendus des publications de 2019-2020

Viola Allegranzi. Aux sources de la poésie ghaznavide. Les inscriptions persanes de Ghazni (Afghanistan, XIe XIIe siècles)

Iván Szántó

(2) OpenEdition

Journals

Electronic version

URL: https://journals.openedition.org/abstractairanica/52112

DOI: 10.4000/abstractairanica.52112

ISSN: 1961-960X

Publisher:

CNRS (UMR 7528 Mondes iraniens et indiens), Éditions de l'IFRI

\title{
Electronic reference
}

Iván Szántó, "Viola Allegranzi. Aux sources de la poésie ghaznavide. Les inscriptions persanes de Ghazni (Afghanistan, XIe - XIle siècles)", Abstracta Iranica [Online], Volume 42-43 | 2021, document 3, Online since 30 December 2020, connection on 13 December 2022. URL: http://journals.openedition.org/ abstractairanica/52112 ; DOI: https://doi.org/10.4000/abstractairanica.52112

This text was automatically generated on 13 December 2022.

All rights reserved 


\title{
Viola Allegranzi. Aux sources de la poésie ghaznavide. Les inscriptions persanes de Ghazni (Afghanistan, XIe - XIIe siècles)
}

\author{
Iván Szántó
}

\section{REFERENCES}

Viola Allegranzi. Aux sources de la poésie ghaznavide. Les inscriptions persanes de Ghazni (Afghanistan, XIe - XIIe siècles). Paris : Presses Sorbonne Nouvelle, 2019, vol. 1: 285 p., 31 ill., vol. 2: 235 p., 228 cat. nos., 10 pls.; ISBN 978-2-87854-981-2

1 This comprehensive survey is published more than half a century after the last - and first - monograph about the subject, The Küfic Inscription in Verses in the Court of the Royal Palace of Mas'ū found out that most of the epigraphy from the palace were to be read in Persian, the discovery was justly hailed as a major scientific breakthrough, given that earlier attempts at deciphery (including Bombaci's own initial efforts) had presumed that Kūfic script must denote Arabic. Allegranzi's essay does not have similar sensations in store for the reader, yet it fully supersedes the former study. It does so on three main grounds: firstly, it identifies some essential shortcomings in the earlier volume; secondly, its scope is far wider, and thirdly, it avails itself of the results of recent scholarship. Moreover, this book is only part of the even more ambitious Islamic Ghazni project, led by Roberta Giunta (ongoing since 2004).

2 With regard to Bombaci's work, Allegranzi points out that his accurate reading of inscriptions came at a cost to the comprehensiveness of the volume as a whole. Bombaci omitted, without explanation, numerous readily available stone slabs, rendering these undeciphered panels invisible in his book. Allegranzi, conversely, aims 
to include, describe, translate, and interpret the material in is entirety, be it in situ, ex situ, dispersed, lost, or fragmentary. While Bombaci included only 116 inscriptions originating from the main hall of the palace, Allegranzi raises this number to 228, spanning the entire site. In addition, she opens up multiple ways to contextualise the ensemble, relying on historiography, art history, paleography, philology, and prosody.

The study and the catalogue are divided into two volumes. The catalogue (volume 2) arranges the 228 panels under discussion according to their location across the different areas in and around the palace, including eight funerary monuments at Ghaznì (ziyāra). It also lists inscriptions the provenance of which cannot be identified. Descriptions are provided in a two-level scheme. On the first level, each individual panel is shown in a b/w photograph, supplemented with a general description, dimensions, an indication of the findspot, and a list of references. On the second level, contiguous elements and texts are treated together, once the constituents of such ensembles are described individually on the first level. Corresponding texts are transcribed and translated, prosodic and paleographic features provided and alternative readings indicated where available.

4 After a detailed account on the state of research (which continues on pp.47-54), volume 1 sets out to summarise the constraints hampering investigations: quite like they did in the 1960s, these constraints include the impossibility to re-establish the original sequence of the verses and the continuing unavailability of at least a single line from an external source, i. e., a manuscript. The author then introduces the Ghaznavid capital as a cultural centre where Persian poetry enjoyed an unprecedented status as a tool to extol the virtues of the ruling dynasty (p. 18). Through an overview of the "first" and "second schools" of Ghaznavid poetry, the author engages the issue of authorship in early New Persian literature and the problems related to textual transmission, referring, among other works, to a newly-emerged copy of the Šahriyārnāma and the possible post-Ghaznavid involvements in its compilation (p. 26). This is followed by a political history of the Ghaznavids and a historiography of the site, the latter being increasingly regarded as a conglomerate of Ghaznavid and post-Ghaznavid (Ghurid and even Khwarazmian) constructions (p. 46). It then provides an overview of the surviving (or, at least, documented) inscribed/decorated items, of which about 550 are marble panels and a similar amount are alabaster fragments, while a much more numerous group (over 4000 items) consists of cheaper bricks and stucco. It also examines the decorative elements according to their current locations as well as whether these represent their original contexts. Chapter 3 is a study in paleography, comparing the material with nearby examples of "foliated Küfic", in addition to inscriptions from Khorasan and Transoxiana, among them Qarākhānid and Bānijūrid monuments (p. 102).

5 The next chapter looks at the subject from the perspective of prosody and establishes, on the basis of the readings of Bombaci and Monchi-Zadeh, that the text was composed partly in the mutaqärib metre and in masnavi form and partly in the mujtass metre, perhaps also in masnavi form, although qașida cannot be ruled out either, while the question whether the different metres point to separate compositions remains unresolved (pp.105-116). Offering comparanda from 11th-12th-century poetry employing these metres and forms, the next section also considers rhymes, before moving on to the thematic aspects of the surviving verses. Among these, royal titles and epithets and the deeds of the Ghaznavid dynasty stand out, allowing the distant 
contours of a versified royal genealogy (nisbatnāma) to emerge, in which respect attention is drawn to the single attested (though lost) pre-Mongol dynastic masnavi, composed by the Ghūrid court poet FaH̆r al-dīn Mubārakšāh (p. 143). Other key themes include religion, notably šarǐ ${ }^{-} a$-based Sunni theology and its institutions (p. 164), royal duties and pastimes, images of time and space, objects of luxury and opulence. To sum up this section, Allegranzi suggests that while all the inscribed fragments might have originated from a single workshop datable to the 11th-early 12th centuries, the possibilities that they contained separate texts and that they were intended for more than a single location cannot be ruled out (p. 191). The final chapter (no. 5) locates the Ghaznī marbles in the context of mediaeval Persian monumental epigraphy and concludes that in many respects the value of the Ghaznavid material might exceed the significance of its regional counterparts: not only the former constitutes a much larger corpus but it preserves by far the earliest tangible vestiges of Ghaznavid poetry.

\section{AUTHORS}

\section{IVÁN SZÁNTÓ}

Eötvös Loránd University (ELTE), Budapest 